\title{
Transformation of Amongraga Actions in Novel Amongraga \& Tambangraras: 40 Malam Mengintip sang Pengantin
}

\author{
Pardi $^{1}$, Teguh Supriyanto ${ }^{2}$, Rustono $^{3}$, Hari Bakti Mardikantoro ${ }^{4}$ \\ \{tarunayes@yahoo.co.id ${ }^{1}$ \} \\ Balai Bahasa Yogyakarta ${ }^{1}$, Universitas Negeri Semarang ${ }^{234}$
}

\begin{abstract}
Serat Centhini (SC) is a monumental Javanese literary, an encyclopedia, and a masterpiece. This study is motivated by the absence of research on the transformation of Amongraga's (the main figure in the novel) actions in SC and Novel Centhini (NC). This stidy aims at revealing the transformation of Amongraga's actions. This study used transformation of literature with comparative techniques to find out the similarities and differences of Amongraga's actions in SC and NC. Based on the analysis, it can be seen the transformation of Amongraga's actions in NC is in the form of decrease, addition, development, and deviation from SC. The significance of this study is to provide information that $\mathrm{NC}$ is not $\mathrm{SC}$, meaning Amongraga in $\mathrm{NC}$ is different from the one in SC. It shows transformational literacy works are different from hipograms so that understanding SC cannot only rely on NC.
\end{abstract}

Keywords: transformation, actions, additions, deviations

\section{Introduction}

Serat Centhiniin a Javanese letter and which is the work of the Surakarta-shaped song of macapat, a monumental work in traditional Javanese literature. Serat Centhini (abbreviated as $\mathrm{SC}$ ) is recognized as an encyclopedia of Javanese culture because of its variety of content so that it is regarded as monumental work, encyclopedia masterpiece of Javanese culture, parent of Javanese knowledge, and Javanese masterpiece. As a major work, SC received appreciation from a number of authors in the form of SC transformation into Indonesian novels. One of the Indonesian literary novels resulted from the transformation of SC is Centhini: 40 Malam Mengintip Sang Pengantin.

This study discusses the transformation of the Amongraga's (the main figure in the novel) actions in Centhini: 40Malam Mengintip Sang Pengantin (hereinafter NC refers to Novel Centhini). Choosing the topic of the transformation of SC in NC is motivated by the need to reveal the similarities and differences in Amongraga's actions, especially in terms of Amongraga's story before forty days of marriage until his separation from Tambangraras in which there has been no study on the transformation of Amongraga's actions in SC. The research problem addressed in this study is how the similarities and differences of Amongtaga's actions are in SC and NC as the transformation work of SC. This study aims at revealing the similarities and differences between Amongraga's action in SC and $\mathrm{NC}$ and finding out the characteristics of transformation in the form of decline, addition, development, reduction, or deviation. 
This study used literary transformation theory with comparative methods. Teeuw (1983) states that literary works are not born of cultural emptiness. The emergence of literary works as a response of a previously published work is that the meaning must consider the hypogram text. The relationship between hiprogram text and transformation can be realized in the form of decline, development, opposition, and rejection. $\mathrm{NC}$ is Wirodono's response to SC as a hypogram text. Research data of this study is in the form of Amongraga's actions in SC and NC.

\section{Research Methodology}

This study of literary transformation of Amongraga's actions in NC employed description method with comparative techniques. The steps in conducting the study was initially describing Amongraga's actions in SC and NC. Then, a comparison was made between Amongraga's actions in the SC and the actions in NC. From the comparison of the actions an analysis was carried out to find out the similarities and differences of Amongraga's actions in hypogram text and transformation texts. The difference of Amongraga's actions was analyzed to see the nature of the transformation of Amongraga's actions. From the analysis of differences and similarities between Amongraga's actions in SC and NC, conclusions were drawn to reveal the characteristic transformation in the form of imitation, addition, deviation, and rejection. The final step was to conclude the transformation of Amongraga's actions from $\mathrm{SC}$ in NC.

\section{Results and Discussion}

Transformatively, NC takes the element of SC stories, including characters, actions, and story settings. Some of the figures transformed in NC are Tambangraras, Amongraga, Centhini, Cebolang, etc. Meanwhile, the storyline in the SC that was transformed, among others, was Jambu Karang and Wanamarta. However, the story element in the SC is modified in NC. Therefore, NC is classified as a formal transformation which varies and differentiates the transformation of elements in the structure of the story. In comparison, Amongraga's actions in the hipogram and transformation text can be described as follows.

In SC 5, respectively, Amongraga had the following activities. Amongraga arrived at Wanamarta and met Ki Panurta who was teaching the santri (p. 142). Amongraga said that he came from Gunung Karang and would learn from Ki Panurta (p. 147). Amongraga explained the knowledge of null and void, usury, circumcision, and fardu. Amongraga had a dialogue with Ki Panurta about the science of Islam (pp. 151-157). Amongraga explained the notion of suspicious sports and sporting suspicion at the request of Ki Panurta (p. 159). Amongraga explained the main behavior to Ki Panurta, etc. Then, Amongraga narrated the war between Giri and Mataram (p. 172, compare to the study of Istanti, 2010; Sidik, 2016).

After a few days of living in Wanamarta (in SC 5) Amongraga stated that he was willing to be married to the Tambangraras when danced 'asked' by Ki Panurta (p. 172). To Ki Suharja, Amongraga said he was from Gunung Karang (p. 176). Amongraga asked for his marriage to be carried out simply (p. 186). On the night before the wedding ceremony Amongraga talked at Jayengwesthi's house. Amongraga requested that his marriage did not need to use offerings and not over-decorated (pp. 1-2). Amongraga said about the wedding 
and stated that he could be sued for divorce if he left his wife 3 years at sea and 7 months on land. Amongraga did a 'respect' 'take a bow' to Ki Panurta and Ki Wanahita (pp. 33-34). Amongraga asked Nyi Malarsih to move the loro blonyo statue near the aisle (p. 54).

In SC 6, Amongraga explained to Tambangraras about the science of mukamat and the obligation of the wife to obey her husband (pp. 59-61). Amongraga explained to Tambangraras about the legal requirements for prayer (p. 62). Amongraga asked Tambangraras about his relationship with Centhini (p. 64). Amongraga echoed the dawn call to prayer in a good voice (p. 66). Amongraga explained the content of the Book of Ibn Fajar (pp. 71-75). Amongraga explained qiraat Fatikah letter to Tambangraras. Amongraga was paraded to Jayengwesthi's house and in the evening explained the meaning of Fatikah letters, movements, and readings in prayer (pp. 87-88). Amongraga asked Tambangraras to teach knowledge to Centhini (SC 6: 116). Amongraga was paraded to Jayengraga's house (p. 151). Amongraga explained to Tambang that there was a need for someone to understand the Shari'a, the tarekat, the essence, and the statement (pp. 207-212). Amongraga explained the year of kamsiyah, arbangiyah, and jamangiyah, and the name of the moon and wuku, Javanese calendar, and ill-fated days to Ki Panurta (SC 6, pp. 223-224 and SC 7, p. 4). Amongraga explained the secret knowledge and revelation of jatmika to Tambangraras. Amongraga felt happy because Tambangraras and Centhini had understood the knowledge he conveyed (pp. 713). Amongraga explained to Tambangraras about praise to God based on the sanctity of the heart. Amongraga explained the law of usury in the presence of Ki Panurta in the Wanamarta (pp. 15, 17, and 20).

In SC 7, Amongraga was paraded to Ki Wiradhusta's house (p. 23). Amongraga explained the conditions for fasting Ramadan at the request of Ki Panurta (p. 27). Amongraga explained eleven types of daim and perfection of worship to the Tambangraras (pp. 33--34). Amongraga explained the pillars of Islam at the request of Ki Panurta (p. 31). Amongraga explained five obligations of fellow Muslims and five obligations of Muslims in matters of the hereafter (pp. 49-50). Amongraga explained death and several types of prayer to Tambangraras (pp. 66-68). Amongraga became kothib on Friday prayer (p. 82-83). Amongraga explained goodness and ugliness at the request of Ki Panurta (p. 91). Amongraga explained the hadith of the Prophet about a person who was loved by God (p. 95). Amongraga explained the knowledge of the origin of human life to the Tambangraras (pp. 100-103). Amongraga criticized the habits of the Wanamarta people who liked to eat. Amongraga explained the perfection of life in the Kitab Tanbihul Apilin, the Kitab Sitin, and the Kitab Asmarakandi, the nature of women, the nature of men, the nature of God, the nature of wives, the time of satanic temptations in human life, and the Serat Sabda Jati content to Tambangraras (p. 116-130).

Amongraga explained the four cases in one's life and the science of copulation (asmaragama, asmarayoga, asmaranala, asmaratantra, asmarajuwita, SC 7: pp.134-136). After doing copulation, Amongraga did not pray in congregation anymore, making the Tambangraras even more sad. Amongraga told Tambang that his sadness was caused by his desire to go looking for his younger siblings. Amongraga said if he died, Tambangraras could marry again by choosing a good man. After that, Amongraga felt that he embraced the Tambangraras (pp. 134-139). When Tambangraras slept, Amongraga told Jamal and Jamil would leave Wanamarta. Amongraga returned to his room to write three letters placed under the pillow of Tambangraras. Amongraga kissed his wife's forehead and whispered asking for goodbye when Tambangraras fell asleep. Amongraga left Wanamarta through the back door. In the first letter, Amongraga ordered and hoped that Tambangraras would remain safe (p. 141). 
$\mathrm{NC}$ does not take all of Amongraga's actions in the SC. Amongraga carried out a number of actions not found in the SC. Some of Amongraga's actions which were not found in the SC were to invite Tambangraras to the musala (in the SC not to invite Tambangraras), to ask the female congregation to leave the mosque because he would explain special knowledge to men, and thank Centhini for the 7th night Tambangraras ( pp. 84-132). In SC, Amongraga had never had a dialogue with Centhini. Amongraga explained five important things in life ( $\mathrm{p}$. 172). In SC, only mentioned Amongraga explained the obligations of fellow Muslims (addition or development transformation). In the SC, Amongraga does not explain ugliness, loneliness and greed (as a form of deviation from hypograms).

In the SC, Amongraga did not ask Centhini to rest while working, not explain to the Tambangraras about death-life, and evils, glory-evil (pp. 213-217). Amongraga did not ask Centhini for his longing for parents (p. 240). Amongraga explained to Tambangraras about honesty (p. 253). Amograga did not advise Centhini to memayu hayuning bawana (p. 263). Then, Amongraga did not invite Tambangraras to sit in the backyard of Wanamarta's house (p. 283). Amongraga was asked to find a good day to move to a new house by Ki Panurta (p. 292). Amongraga told Centhini that Mataram spies were looking for Sunan Giri's child (p. 313). Amongraga told Centhini that he would leave Wanamarta looking for his two siblings (p. 313). Amongraga asked Centhini to look after the Mine Mine (pp. 315 and 351). Amongraga did not tell his life journey to Centhini (p. 360). Amongraga met three people in the backyard of Wanamarta's housr (p. 409). Amongraga explained the development of the fetus to Tambangraras and Centhini (pp. 448-450). All Amongraga actions in the NC above are deviations from the SC. From the description of Amongraga's actions in the NC above, there are differences in Amongraga actions in the $\mathrm{NC}$ with $\mathrm{SC}$. The transformation of Amongraga actions in the NC does not only emulate, but adds, develops, and deviates from Amongraga's activities in the SC.

\section{Conclusions}

After conducting the discussion, conclusions can be drawn (1) Centhini (NC) novel by Sunardian Wirodono is a formal transformation of the SC text, (2) Amongraga actions in NC are not the same as Amongraga in SC. (3) Amongraga's actions in the SC were not taken in the $\mathrm{NC}$, while a number of Amongraga actions in the $\mathrm{NC}$ were not found in the SC, (4) Amongraga in the $\mathrm{NC}$ was not Amongraga in the SC, and (5) Amongraga's transformation in the form of decline, development, addition, and deviation. Furthermore, the figures examined the actions of prominent figures in the $\mathrm{NC}$ on a comprehensive $\mathrm{SC}$ (on the figures of Tambangraras, Centhini, Cebolang, Jayengraga, Jayengresmi, Nyi Malarsih, Ki Panurta, etc.) revealed more comprehensive characteristics of $\mathrm{NC}$ transformation over SC. 


\section{References}

[1] Jauss, Hans Robert. Leterary History as a Challenge to Literary Theory in New Directions in Literary History (Ralph Cohen, Ed.). London: Routledge \& Keegan Paul (1974)

[2] Istanti, Kun Zahrun. Transformasi dan Intergrasi dalam Kesusastraan Nusantara: Perbandingan Teks Amir Hamzah Melayu dan Jawa. Jurnal Humaniora. Vol. 12. No. 3. pp. 241-249 (2010)

[3] Junanah. Kajian Morfosemantis terhadap Serat Centhini dalam Jurnal Millah, X (1). pp. 101-125 (2010)

[4] Junus, Umar. Resepsi Sastra: Sebuah Pengantar. Jakarta: Gramedia (1985)

[5] Kamajaya, Karkana. Serat Centhini sebagai Sumber Inspirasi Pengembangan Sastra Jawa. Semaran: Kongres Bahasa Jawa II (1996)

[6] Muslifah, Siti. Akulturasi Budaya Timur Tengah ke Indonesia dan Pengaruhnya dalam Kesusastraan: Studi Kasus pada Serat Centhini. Jurnal CMES. VI (1). pp. 103-111 (2013)

[7] Nurnaningsih. (2015). The Metaphors of Sexual Organs, Sexual Activities, and Sexual Activities Impacts in Serat Centhini, Written by Pakubuwana V. International Journal of Language and Linguistics. Vol. 2. No. 5. pp. 214-222 (2013)

[8] Pradopo, Rachmat Djoko. Beberapa Teori Sastra, Metode Kritik, dan Penerapannya. Yogyakarta: Pustaka Pelajar (2010)

[9] Riffatere, Michael. Semiotics of Poetry. Indiana University Press: Bloomington-London (1978)

[10] Sidik, Umar. Transformasi Kisah Ashabul Kahfi dalam Ahlul Kahfi Karya Taufiq Al-Hakim. Jurnal Widyaparwa. Vol 44 No. 2. pp. 110-123 (2016)

[11] Teeuw, A. Membaca dan Menilai Sastra. Jakarta: Penerbit Gramedia (1983)

[12] Wibawa, Sutrisna. Nilai Filosofi Jawa dalam SeratCenthini. Jurnal Litera. Vol. 12, No. 2. pp. 328-344 (2013)

[13] Wibawa, Sutrisna. Moral Philosophy in Serat Centhini: its Contribution for Character Education in Indonesia. Asian Journal of Social Sciences \& Humanities. Vol. 2, No. 4, 2013. pp. 174-184 (2013)

[14] Wirodono, Sunardian. Centhini: 40 Malam Mengintip Sang Pengantin. Yogyakarta: Diva Press (2009) 